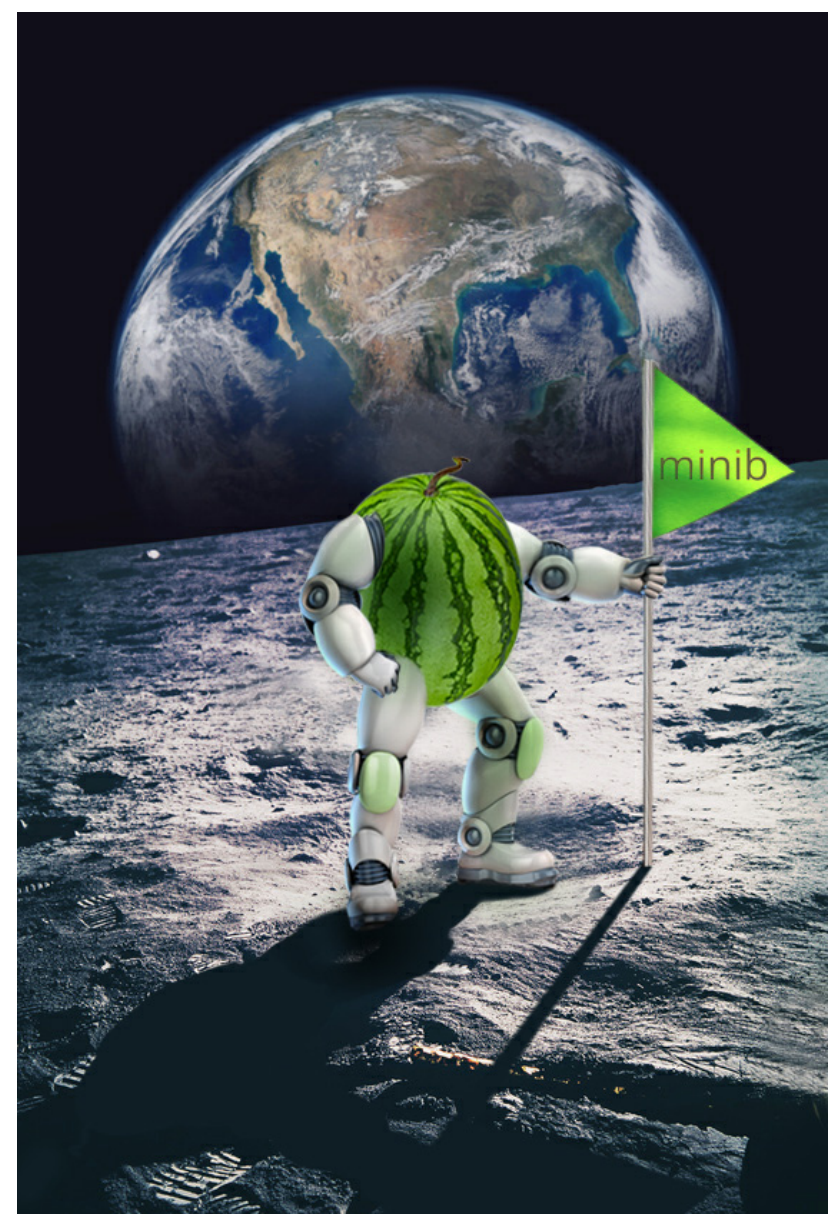

\title{
MARKETING FOR SCIENCE BASED ORGANIZATIONS PERSPECTIVES AND QUESTIONS
}




\title{
Sciendo
}

\section{MARKETING FOR SCIENCE BASED ORGANIZATIONS PERSPECTIVES AND QUESTIONS}

\author{
prof. William Bradley Zehner II \\ IC2 Institute, University of Texas at Austin, USA \\ wbzehner@gmail.com \\ Jacquelyn Anne Zehner \\ Facebook, Texas at Austin, USA \\ jazehner@gmail.com \\ DOI: 10.2478/minib-2019-0031
}

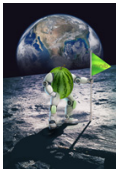

\section{Summary}

Marketing for research and science-based organizations is complex and not well understood; especially by the research, scientific, and technical communities. This paper presents a conceptual framework for scientists in research and sciencebased organizations to think about their organization's marketing and sales functions, and related processes. NASA, one of the world's most successful research organizations, which put two American astronauts on the moon in approximately 8 years, is briefly explored. The role of 21 st Century research and science-based organizations in creating societal, organizational, and individual wealth is examined via a conceptual framework of the virtuous wealth creation process. Two forms of intrinsic organizational cultural conflict are examined; the external cultural conflicts between potential customers and the technology organization, and the internal conflict between scientists and economic managers. Strategic marketing is addressed and consists of market need, market segmentation, choosing a target market, and the organization's position relative to the target market and competition. Tactical marketing (AKA sales) and its elements are delineated - product, price, promotion, physical distribution, and most importantly - personnel. The integration of all elements of strategic and tactical marketing into a cohesive whole is underscored. Additionally, several marketing and sales questions are posed to facilitate self-assessment by research and technology-based organizations.

Keywords: commercialization, marketing, organizations, sales, science, research, technology, wealth 



\section{Introduction}

This paper assists scientists and engineers in understanding the role of marketing in for science and research-based organizations. Marketing for research and science base organizations is both complex and frequently misunderstood by individuals in the technically-focused sectors of those organizations since the organization's core competency is knowledge.

An illustrative case for a successful research and science-based organization is examined; the US National Aeronautics and Space Agency (NASA) which landed two astronauts on the moon in eight years after the initial challenge to do so. Four additional topics are explored in this article. These topics include wealth creation from research and science in the 21 st Century; the virtuous cycle which illustrates the process by which wealth is created from science and technology; and the role of marketing at both the strategic and tactical levels in wealth creation. Lastly, questions are posed for research and science-based organizations self-assessment.

Research and science-based organizations are similar in that both types of organizations are built on a foundation of knowledge. The focus of research organizations such as universities and research institutes are knowledge creation. The focus of science-based organizations is on knowledge dissemination and monetization via societal products and services. Obviously, there is a great deal of overlap between the two types of organizations. Research organizations may license their knowledge and science-based entities frequently engage in research to improve their products and services.

For brevity in this paper, both research and science-based organizations will be referred to as "technology or technology-based organizations" even though they are somewhat different, their roots are grounded in science and technology. Additionally, we recognize that technology-based services and products are different but share the common characteristic of being knowledge based. Services are normally consumed at the time they are produced. An example would be a physician counseling a patient. In contrast, the creation of products is separated from their consumption or use. Again, for brevity, appreciating the intrinsic differences, products and services will be collectively referred to as simply "products". 


\section{The US National Aeronautics and Space Agency (NASA) A Brief Illustrative Case Study of a Successful Research and Science Based Organization}

On the 25th of May 1961, US President John F. Kennedy proclaimed, "This nation (USA) should commit itself to achieving the goal, before the decade is out, of landing a man on the moon and returning him safely." The "moon mission" was named the Apollo program. On July 20th, 1969, eight years and one month after President Kennedy's challenge, US astronauts Neil Young and Buzz Aldrin stepped on the surface of the moon. There were 5 subsequent moon landings after the first landing. The last US NASA moon landing was on 7th December 1972.

The Apollo program was America's response to the strategic threat posed by the Soviet Union's recent successes in space exploration. These included the Russian launch of the first satellite, Sputnik, in October 1957; followed by the Russian cosmonaut, Yuri Gagarin, becoming the first man in space in April 1961. The Soviet Union's strategic threat to the USA was further underscored by the Cuban Mission Crisis in October, 1962.

The US Apollo Program (along with the Manhattan Project to build the atom bomb during World War II) embodied the focus on investment in fundamental research and science that led to the many of the major technological achievements of the 20th Century. Both programs advanced mankind's knowledge of fundamental science and then translated the science into technologies instrumental to achieving the programs' objectives.

To implement the Apollo Program's "moon mission", the US's National Aeronautics and Space Agency's (NASA) funding was dramatically increased to increase research and development ( $R \& D$ ) funding. Adjusted for inflation, NASA's cumulative "moon mission" funding was approximately $\$ 213$ billion USD. The actual costs of the Apollo program are notoriously difficult to quantify accurately since research and development was distributed among government and university laboratories as well as in public and private companies. At the Apollo's program peak, the program's budget accounted for about 
ok.5\% of the US's GDP, and approximately 4 to $5 \%$ of the US's Federal Government spending. "In 2018 dollars, the Apollo era budget would have been equivalent to each American paying over $\$ 213$ a year to the space administration (Stirone 2018)."

How did NASA market the Apollo program to US citizens to secure program funding? By publicizing the number of jobs created. NASA recognized that the US congressional representatives were extremely interested in the economy and jobs in their districts, since securing local jobs was a well-known tactic to secure future votes for themselves.

The US Congress is divided into the Senate (the upper house) with 100 senators and House of Representatives (the lower house) which contains 435 representatives aka Congressman. In the American political process, the lower house controls all government spending so NASA focused on the Congressional representatives to market the Apollo program to secure funding support, NASA estimated the number of jobs which would be created for each senator and representative by the Apollo program. Since most of the Apollo program challenges and tasks were scheduled to be subcontracted to public and private US companies, NASA shared their economic and job analyses with the privately-owned companies. The companies in turn retained Washington D. C. lobbyists to convince the Congressional senators and representatives to support the Apollo program while engaging in a massive public relations campaign to simultaneously develop "grass roots" support at the voters' level. This marketing campaign was centrally coordinated by NASA. It worked. At its peak in 1969, the Apollo program was responsible for approximately 409,000 jobs - approximately one out of every two hundred workers in the USA.

Why was the Apollo Program successful? Peter F. Drucker, the business philosopher and "the man who invented management" offers insights to the Apollo Program's performance in his book The Five Most Important Questions You Will Ever Ask about Your Organization. Table 1 presents Drucker's five questions as they relate the Apollo program. The Apollo Program was a research, scientific, and technological success due its clear, specific, and time bound mission, phased action 
plan, and keenly defined primary and secondary customers. It was also important to have a crystalline understanding of the Apollo Program's need - security - and related value for Americans and specific metrics to measure progress and success in a time phased plan.

Table 1. Peter F. Drucker's Five Important Questions Applied to the Apollo Program

\begin{tabular}{|c|c|c|c|}
\hline & Drucker Questions & Apollo Program & Observations \\
\hline 1 & What is our mission? & To/from moon by 1970 & Specific \& time bound mission \\
\hline 2 & Who is our customer? & $\begin{array}{l}\text { Primary: American PublicSecondary: } \\
\text { US Congress }\end{array}$ & $\begin{array}{l}\text { American public = ultimate customer } \\
\text { via US Congress = funder \& actual } \\
\text { buyer \& public relations campaign } \\
\text { directed toward the voters }\end{array}$ \\
\hline 3 & $\begin{array}{l}\text { What does the customer } \\
\text { value? }\end{array}$ & National security & Security \& safety \\
\hline 4 & What are our metrics? & Time phased milestones & $\begin{array}{l}\text { Specific and measurable time } \\
\text { phased milestones from research to } \\
\text { science to technology }\end{array}$ \\
\hline 5 & What is our plan? & Management \& funding controlled by NASA & $\begin{array}{l}\text { NASA manages Apollo program } \\
\& \text { awards contacts controlling } \\
\text { funding }\end{array}$ \\
\hline
\end{tabular}

The Apollo Program illustrates classical marketing theory of finding a need ("national security and prestige"), designing a product to address the need ("national security and prestige"), and marketing it to target customers (US Congress, private industry, and the voters) by showing all parties, "what is in it for them". The Apollo program was successful since the National Aeronautics and Space Agency (NASA) created a clear vision and action plan in line with Dr. Drucker's five questions.

The senior management teams of science-based organizations generally cannot agree on Drucker's five questions. How would your organization answer Dr. Drucker's five questions? 


\section{Wealth Creation in the 2lst Century}

Organizational research and development (R\&D) and technology are the drivers of knowledge-based wealth creation in the 2lst Century. This section and virtuous cycle figure explain the wealth creation process and key roles of the knowledge creators and the knowledge applicators.

Over time, a number of new products and industries emerged from the Apollo program such as aircraft collision avoidance systems, cordless power tools, computers, corrosion resistant coatings, digital imaging, global positioning satellites, heart-lung machines, implantable pacemakers, infrared cameras, internet, kidney dialysis machines, Lasik eye surgery, virtual reality, and weather forecasting models (Folger, 2012). "It is estimated that the total economic benefit of each dollar spent on the space program has been between $\$ 9$ and \$11 (Fowler, 2014)."

In the 21st Century, science and technology are wealth creators at the societal, company, and individual levels. "There are a number of ways to measure society's economic wealth. Wealth is commonly measured as Gross Domestic Product (GDP) at a country level which measures a nation's economy, market valuation at a company level, and net worth at the individual level" (Zehner, Williams, \& Pletcher, 2016). In 1961, at the dawn of the Apollo program, world GDP per capita in constant US dollars was $\$ 3,192 /$ capita and today is approximately $\$ 10,714 /$ capita - a 3.36 x increase (Data Market \& World Bank data, 2018).

Science and technology drove this increase in global wealth. In "Technical Change and the Aggregate Production Function" Robert Solow, a MIT economist and 1987 Nobel Prize recipient in economics, concludes that "gross output per man hour doubled over the interval (studied), with a 871 per cent of the increase attributable to technical change and the remaining 121 per cent to increased use of capital" (1957). Innovation and technology are primarily responsible for approximately $87.5 \%$ of the world's increase in wealth and standard of living. 
Building on Robert Solow's work, Paul Romer, a New York University Stern School economics professor and former Chief Economist of the World Bank who was awarded 2018 Nobel Prize in Economics "for integrating technological innovation into long term macro-economic analysis" (Wang, 2018). Romer's ideas are summarized in his article titled "Endogenous Technological Change" as "technological change... lies at the heart of economic growth... that technological change arises in large part because of intellectual actions taken by people who respond to market incentives... instructions for working with raw materials (intellectual knowledge) is inherently different for other economics goods. This property is the defining characteristic of technology (1990)."

The wealthiest global companies create societal wealth through their roots in technology and innovation. This is illustrated by the following table which shows that nine of the top 10 wealthiest companies (based on market capitalization) rest on a technology foundation (Wartzman \& Crosby, 2018). The Drucker Institute estimates how innovative companies are on a scale of 1 - least innovative to $5-$ most innovative. Note that all ten of the top 10 wealthiest companies received the Drucker Institute's highest rating of five for innovation.

Technology creates individual wealth. Table 3 presents Forbes Magazine 2018 list of the world's Top 10 billionaires. All the billionaires' companies use technology to create customer value. Except for the Koch brothers who inherited a relatively small business from their father and grew it into a large diversified industrial giant, the other eight billionaires were entrepreneurs who created their companies and built their fortunes. Every one of them capitalized on technology, and the underlying layer of scientific research required to create technology, to create, build, and manage wealth. 
Table 2. World's Ten Largest Companies by Market Capitalization and Innovation Rating

\begin{tabular}{c|c|c|c|c}
\hline Rank & Company & $\begin{array}{c}\text { Market } \\
\text { Capitalization (1) } \\
\text { US\$ Billions } \\
\mathbf{0 9 / 2 8 / 2 0 1 8}\end{array}$ & Category & $\begin{array}{c}\text { Innovation } \\
\text { Rating (2) } \\
\text { 1 = Lowest } \\
\text { = Highest }\end{array}$ \\
\hline 1 & Apple & $\$ 1,091$ & Computer - Technology & 5 \\
2 & Amazon & $\$ 977$ & Retailing - Technology & 5 \\
3 & Microsoft & $\$ 877$ & Software - Technology & 5 \\
4 & Google/Alphabet & $\$ 840$ & Search - Technology & 5 \\
5 & Berkshire Hathaway & $\$ 524$ & Retail - Finance & 5 \\
6 & Facebook & $\$ 474$ & Communications - Technology & 5 \\
7 & Alibaba Group & $\$ 424$ & Retailing - Technology & China/NA \\
8 & Tencent & $\$ 388$ & Internet - Technology & China/NA \\
9 & JP Morgan & $\$ 379$ & Finance - Technology & 5 \\
10 & Johnson \& Johnson & $\$ 371$ & Medicine - Technology & 5 \\
\hline
\end{tabular}

Source: https://en.wikipedia.org/wiki/List_of_public_corporations_by_market_capitalization

Table 3. World's Top 10 Billionaires in 2018

\begin{tabular}{c|c|c|c}
\hline Rank & Name & Net WorthUS \$ billions & Company \\
\hline 1 & Jeff Bezos & $\$ 112$ & Amazon \\
2 & Bill Gates & $\$ 90$ & Microsoft \\
3 & Warren Buffet & $\$ 84$ & Berkshire Hathaway \\
4 & Bernard Arnault & $\$ 72$ & LVMH \\
5 & Mark Zuckerberg & $\$ 71$ & Facebook \\
6 & Amancio Ortega & $\$ 70$ & Zara \\
7 & Carlos Slim Helu & $\$ 67$ & Telecom \\
8 & Charles Koch & $\$ 60$ & Koch Industries \\
9 & David Koch & $\$ 60$ & Koch Industries \\
10 & Larry Ellison & $\$ 59$ & Oracle \\
\hline
\end{tabular}

Source: Forbes Magazine - March 6, 2018.

Technology - research and science - in 20th and 21st Centuries plays a significant pivotal role in wealth creation at the individual, company, and national levels. However, the actual mechanism of the wealth creation process is not yet well understood by 
economists. Figure 1 delineates a step by step process of wealth creation as from research funding to new products to new companies which fund additional research directly or via taxes (Trzmielak \& Zehner, 2011).

Figure 1. The Virtuous Wealth Creation Cycle

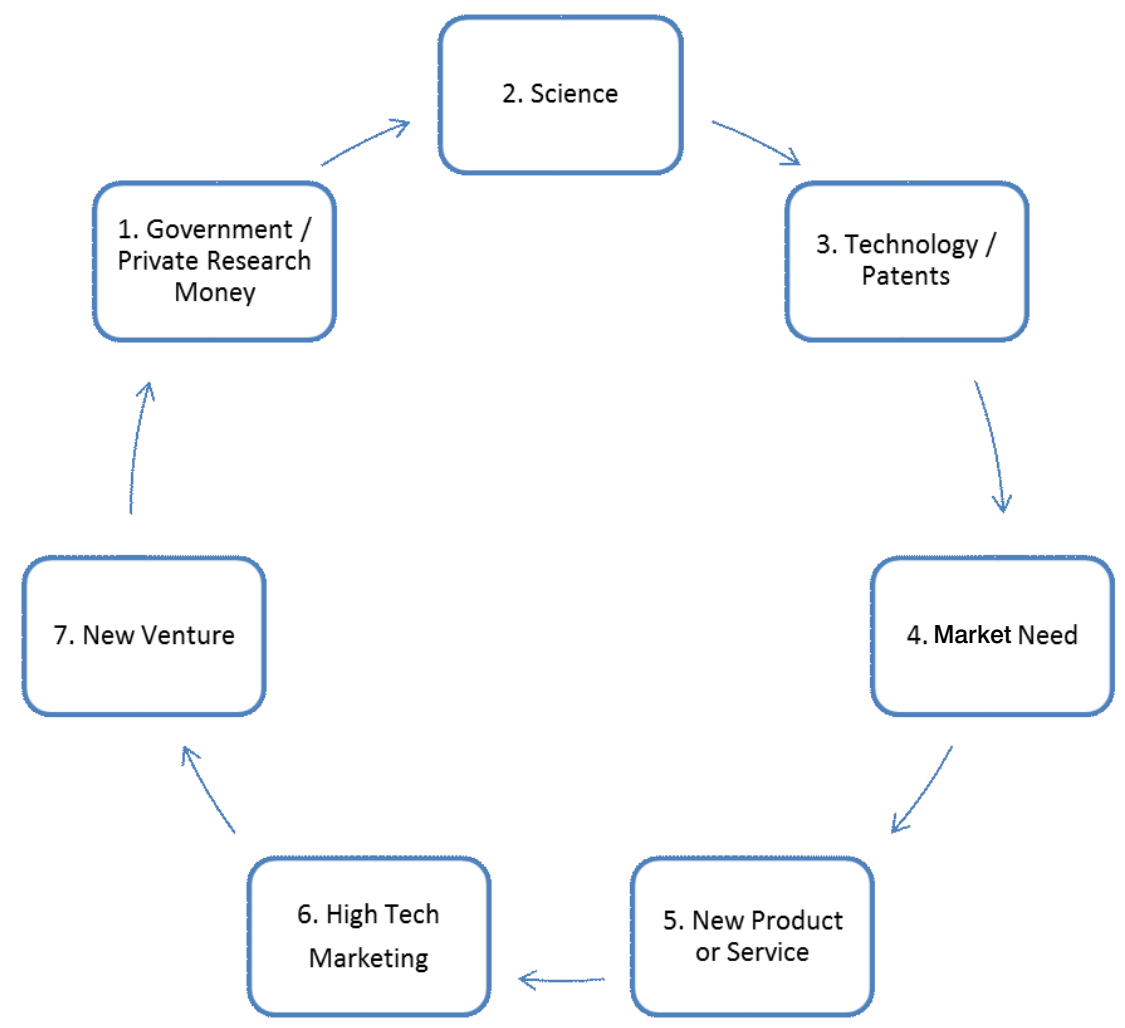

Source : Trzmielak, D. \& Zehner, W. (2011).

Metodyka $i$ organizacja doradztwo $w$ zakresie transferu $i$ komercjalizacji technologii, s. 16

Steps 1 and 2 - Funding and Science

Globally most basic research is funded by government organizations. In some countries like the US it is dually funded by the government and private research institutes. In the 21st Century, 
research amounts to approximately $2.1 \%$ to $2.2 \%$ the world's GDP and is increasing at a rate of $2.9 \%$ annually. Consequently, the number of researchers globally has increased by $1.3 \%$ annually; from 1,082 researchers per million people in 2000 to 1,268 researchers per million people in 2013.

The more researchers there are, the more knowledge created, which is eventually translated into increased wealth. Additionally, research productivity as measured by scientific and technology articles published has increased $11.3 \%$ percent annually from 974,170 articles in 2000 to $2,183,933$ articles in 2013 (Zehner, Williams, \& Pletcher 2016). This increase in research productivity unlocks even greater gains within the virtuous cycle of wealth creation.

\section{Step 3 - Technology and Patents}

Patents may be conceptualized as science converted into technology or potential new products/services. Patents monetize science by granting the patent holder a market monopoly for a limited time period. The number of patent applications worldwide almost doubled from 824,055 in 2000 to $1,624,969$ in 2013 - a $7.5 \%$ increase annually (Zehner, Williams, \& Pletcher 2016).

Not all patents have monetary value. "A 1997 study of 300 patents by Stevens and Burley concluded only one patent out of 300 had significant commercial value" (Zehner, Williams, \& Pletcher 2016, Stevens and Burley 1997).

Whether "to patent or not to patent" is a simple business decision based on market potential, the rate of technological change vs. the cost of the patent and anticipated financial returns. In the US, it frequently takes four years to obtain a patent and costs approximately $\$ 50,000$ USD and once obtained annual fees must be paid to keep the patent valid and in force. 


\section{Steps 4,5 , and 6}

- Market Need

- New Product/Service

\section{- High Technology Marketing}

Marketing is the key to successful commercialization of the technology. A market need must be identified and then matched with a product to address that need. Finally, the product's utility must be communicated to potential customers for purchase.

Peter Drucker (1973) defines a business by explaining that "to know what a business is, we have to start with its purpose. Its purpose must lie outside of the business itself...There is only valid definition of business purpose: to create a customer" by addressing a market need (99). Drucker continues, "It is the customer who determines what a business (organization) is. It is the customer alone whose willingness to pay for a good or for a service that converts economic resources into wealth, things into goods. What the customer buys or considers value is never a product. It is always utility, that is, what a product or service does for him" (98).

Marketing technology products is a question of researching and identifying customer needs. Drucker (1973) points out "the aim of marketing is to know and understand the customer so well that product or service fits him and sells itself" (99). Leavitt, in his classic 1960 article Marketing Myopia iterates, the "difference between marketing and selling is more than semantic. Selling focuses on the needs of the seller, marketing focuses on the needs of the buyer. Selling is preoccupied with the seller's need to convert his product into cash; marketing with the idea of satisfying the needs of the customer by means of the product and the cluster of things associated with creating, delivering, and finally consuming it".

\section{Step 7 - New Ventures}

An entrepreneur recognizes the opportunity to commercialize technology to translate technology into utility to satisfy customer and market needs, and then communicates to market the benefits of 
technology via high tech marketing. This process is frequently referred to as technology commercialization.

If the entrepreneur is successful in bring the technology's utility to the market, a profitable new venture is created which pays taxes to the government to continue the funding governmental research. Additionally, a successful venture may create significant personal wealth which the entrepreneur may use to create private foundations to research specific topics. Thus, continuing the virtuous wealth creation process. The crux of the wealth creation process is marketing of products grounded in science and technology to address societal needs.

\section{The Cultural Challenges}

One of the cultural challenges is the gulf between scientists and business managers. Each group has a different "world view." For product development and marketing success, each group must ultimately understand and appreciate the roles of the other group.

\section{Science vs. Business}

One of the unacknowledged issues for research and scientific organizations is simply the cultural differences between scientists and technologists vs. business and marketing. The gulf begins with education. A scientific and technological education is "narrow" in breadth but very deep in a specific discipline. A business and marketing education is "broad" in breadth but shallow in multiple disciplines.

Professionally, the scientist's and manager's goals are different. The primary goal of a scientist is to produce new scientific knowledge; a technologist's goal is to apply the new scientific knowledge to create a technological solution to address customers' needs. Both the scientist and the technologist tend to devalue an organization's economic goals. 
However, the primary goal of managers is to focus on the financial stewardship of an organization. The manager values economic goals recognizing that the long-term survival of the organization is predicated on achieving economic goals via launching of new products.

Dubinskas (1988) captured the dichotomy between the scientist's and the manager's world view as "the complete adult realist managers, in their struggles with immediate economic necessity, must contend with immature scientists-dreamers; while...the far-sighted progressive scientists must protect their work ...the basis of the firm's wealth... from myopic and developmentally retarded managers." Both perspectives have their place; basic science needs time to progress, and technology needs a long-term technical vision to experiment and produce a viable product, neither can be purely economically motivated or they will fail. However, to support this research and development, technology organizations need managers to keep the labs and research facilities running.

For a new technological product or new technological venture to succeed in the marketplace, both the scientists and managers must recognize that they are locked into a deep symbiotic relationship. Both parties must arrive at a mutual understanding of the other's goals and the other's value to the organization for the organization to succeed. This is the first cultural challenge within scientific and research organizations.

\section{Science vs. Customers}

The second cultural challenge is the external one between the technology organization and potential customers. The customers are concerned with: "Can the technology organization solve the challenge with a workable solution within the contracted time frame and contracted price?" Since the technology organization is frequently pushing knowledge frontiers, its concern is: "Can we do this project within the time frame and contracted price with our staff and other resources?" It's essentially the same risk and professional challenges seen from two different perspectives. 
There is a methodology called "the Quicklook process" to determine the commercial viability of a technology product or service (Zehner \& Pletcher, 2017). The process is straightforward. Scientific experts are contacted to assess the project's technology uncertainty, i.e., "Will the technology work?". Then, potential customers are contacted to address market uncertainty and asked questions such as, "Is there a market need for this product? Who are the competitors? Does the product offer the utility you need? What price would you pay? Under what conditions will the market embrace the project?"

The most efficient and effective way to ensure that the product is on target relative to potential customers' needs is to work closely with potential customers to "co-create" the product or service. A sciencebased organization might select a small group of technologically sophisticated customers who are industry leaders and work closely with them to define the initial product and then refine the project during subsequent iterations. This requires developing trust between the scientific organization and the potential customers as well as among the customers themselves.

To land the contract, a technology organization might use prior challenges to demonstrate to the potential client that they have successfully solved similar challenges within schedule and budget. This approach is most effective when prior satisfied clients are willing to act as reference customers to future customers. A related caveat is that the research organization should not underestimate the time and expenses involved. Completing the project on schedule and under budget will dramatically increase the research organization's reputation in the marketplace.

\section{Marketing for Technology-based Organizations}

This section casts marketing for science-based organization into the classical marketing paradigm. Albeit superficial, this description will give the science researchers and managers a "sense" of the marketing process and the interrelationships among marketing elements. More 
importantly, each description is followed by a series of questions which challenges the scientists and managers in science-based institutions to assess the marketing of their organizations.

\section{Marketing for Products and Services}

Marketing is important for both product and service-based businesses and its definition is broad enough to encompass both. The American Marketing Association (AMA) defines marketing as, "the activity, set of institutions, and processes for creating, communicating, delivering, and exchanging offers that have value for customers, clients, partners, and society at large (AMA, 2013)."

The marketing process is very similar for both product and services marketing. Services' marketing differs from product marketing in intangibility, inseparability, perishability, and variability. Services generally lack physical form which products have. It is difficult to transfer services due to the lack of physical form. Production and consumption of services are intertwined and cannot be separated as in products. Services are perishable and cannot be stored as products may be. Services involve human variability which makes quality difficult to assess and measure.

An organization based on technology can offer tangible products such as computers or intangible services such as hospital care. Most research organizations such as universities and research institutes focus on offering services in terms of knowledge creation which is basically intangible. Some research organizations attempt to measure knowledge creation by counting the number of papers published in scientific and technical journals. Businesses are more likely to offer products such as computers which disseminate technologies throughout society and may use patents granted as a surrogate measure for effectives. Both journal publications and patents awarded have serious issues when used as measurement. However, it must be strongly reiterated that the marketing process for similar for both products and services. 


\section{The Marketing Process}

The marketing process is illustrated in Figure 2 can be segmented into two significant sections. Section 1 focuses on the four strategic elements of marketing such as customer needs, market segmentation, selection of a target market(s), and product / services positioning relative to competition. Strategic marketing focuses on the philosophical issues of what business is the organization in and what market(s) do the organizations elect to serve.

Section 2 focuses on the five tactical elements of marketing such as the actual product/service offered, price and value relative to the status quo and competitors, promotional approaches, supply chain management to move the product/service from the producer to the customer, and marketing and sales personnel.

Each of the strategic and tactical steps requires specialized knowledge and skills to implement. If the strategic marketing is on target it is more likely that the organization will be successful at the tactical level. Successful marketing requires total integration of the nine steps into a cohesive program with feedback loops among the steps. This is a complex management task requiring knowledge, skills, and experience. 
Figure 2. The Strategic and Tactical Marketing Processes

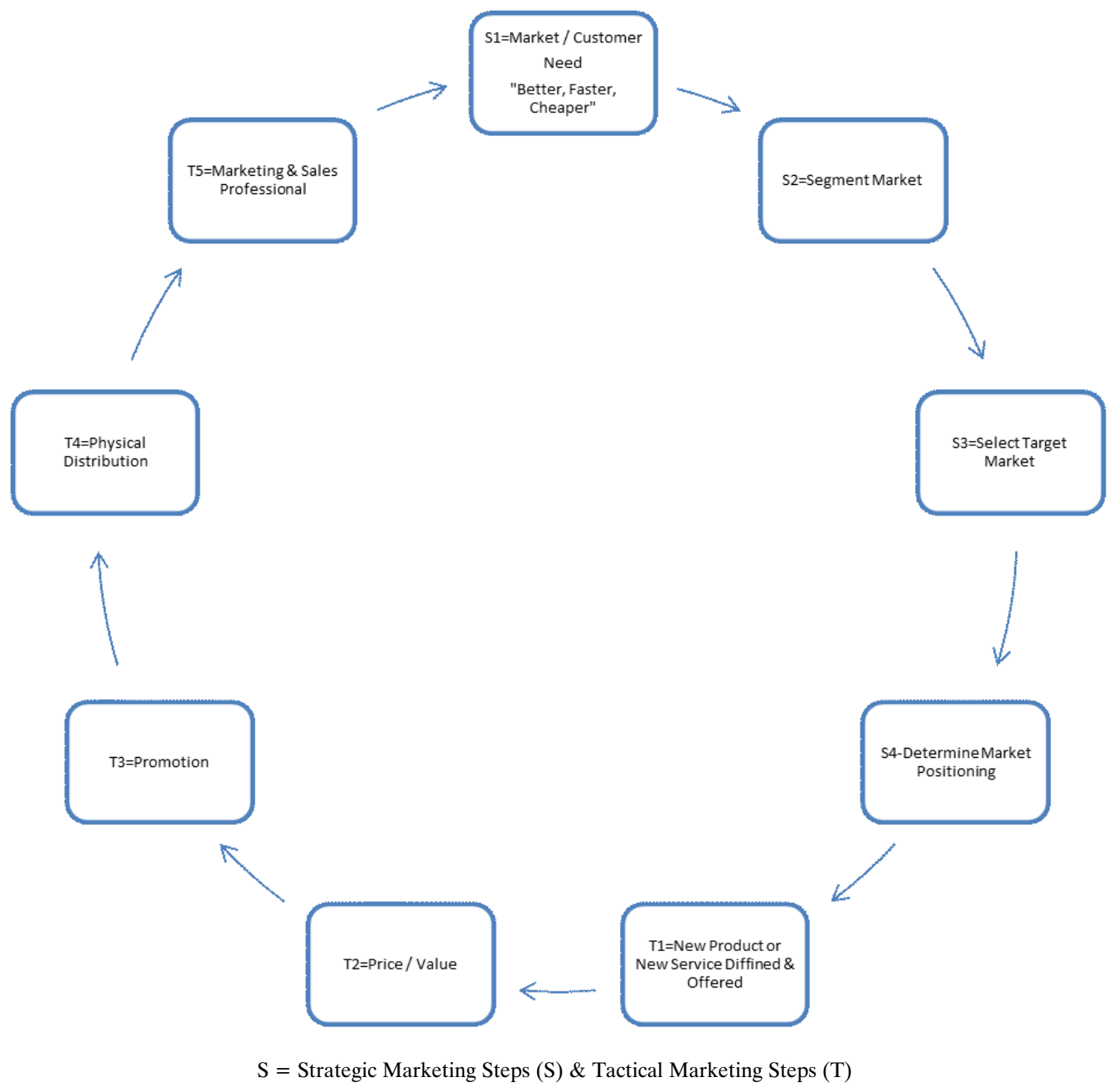

Strategic Marketing

\section{Customer Need}

Strategic marketing really begins with understanding the customer's needs. Many potential customers are constantly searching 
for technologies to improve their lives and operations. "Better, faster, and cheaper" might be the customer's mantra.

Eric von Hippel, MIT professor, pointed out in his early career research that for 111 scientific instrument companies $80 \%$ of significant innovations were invented and prototyped by users (customers). Von Hippel (1976) noted that "approximately three out of four commercially successful industrial product innovations are initiated in response to a perception of user need for an innovation, rather than on the basis of a technology opportunity to achieve them" and "accurate understanding of user need is the factor which discriminates most strongly between commercially successful industrial good innovation projects and those which fail." The unmet need is the customer's initiative to initiate a better technology solution.

Questions: How does your technology organization interact with actual and potential customers?

How well does your organization understand your customers' needs?

How does your organization know about its customers' needs?

What does your organization know about the needs of your non-customers?

\section{Market Segmentation}

Virtually all markets may be sorted into submarkets - clusters of customers sharing common characteristics. This process is called market segmentation. For example, the automobile market may be sorted into a large number of segments with common characteristics which are different from other segments - Rolls Royce and Mercedes occupies the "status" segment, Volvo the "safety" segment, Jaguar and Porsche occupy the "sporty speed" segment, etc.

Sorting the total market into multiple submarkets which share common characteristics to address within the resources of the technology organization is a critical next step after identification of 
market needs. There are a large number of market segmentation schemas ranging from technology to economics to geography to psychological profiles.

Very few technology organizations enjoy unlimited resources, so the one of the initial major decisions is which the market segment should the organization target. Normally, the scientific or technology organization will attack the customer segment which will benefit most the most economically from their organization's knowledge or product.

Questions: What are optimal market segment schemas for your organization's product(s)?

What is the economic value of your organization's product or service in each segment?

Rank order the top three market segments based on your organization's success criteria?

\section{Market Positioning}

The key target market segment is potential customers who benefit the most from the technology the organization offers. The crucial question here is "How will the technology organization position itself in the customer's mind relative to competitive alternatives?" For software, a position might be "does everything but is very expensive" or "does most things needed but is reasonably priced". This means the technology-based organization must understand how the potential customer addresses their need today - the status quo - and where in the customer's mind the competitors are positioned within the target market segment.

Positioning should be a well thought out marketing decision which the organization can influence and defend; otherwise the organization's position will simply emerge in the marketplace. It is important to recognize that all organizations have a position in the customer's mind relative to competition and understand what the position is. 
Questions: How are competitors positioned in the minds of potential competitors relative to the status quo and each other?

How do you know where potential competitors are positioned?

Are there any "open" positions in the target market that your organization can seize and defend?

What actions must you take to create and defend your organization's position?

\section{Tactical Marketing}

\section{Product/Service}

Many research and scientific organizations are not clear about what exactly is their product or service as perceived by potential customers. For example, is the service of a university education or research? From the perspective of a student, it is education. From the perspective of an organization funding research, it is new knowledge. What are the proportions of each?

Another issue frequently baffling research and scientific organizations is a keen definition of exactly what is the product or service offered. What is the core benefit of the actual product or service per se and what is the 'augmented product' which might include installation, if required, warranty, and post purchase service?

The core benefit will most likely improve the economics of the customer by making the customer more effective or efficient. It must be underscored that potential customers do not care about your product/service per se! Customers only care about the benefits your product provides to them - "what's in it for me" - your utility to address the customer's problems.

Technology organizations frequently do not understand or appreciate the potential customer's economics since they are focused inward on their technology. With understanding of the economics of 
potential customers the technology organization may help the customer optimize resource allocation decisions while simultaneously maximizing revenues. For example, many technology products are tailored to the specific customer situation which makes them pricey. If you know that the potential customer's board of director's approves all major expenditures with a two-year payback or less, then you might price your technology at 1.9 years to ensure you capture the order.

Questions: Can your organization define exactly what your core and augmented product is?

Does your organization understand the economic and noneconomic benefits to customers of your product/service?

How do you know that your organization's understanding of customer's product need is valid? What have you assumed? What have you verified?

\section{Price}

Price is the monetary exchange value of the product or service. Price is what the potential customer is willing to pay to acquire the product to make their operations "better, faster, or cheaper". High price generally signals potential customers that the product or service is high quality and high performance. An average price signals average quality and average performance. Value is the economic worth of a product/service to the customer relative to the customer's competitive alternatives.

Value is normally determined by payback - how long it will take to return the original investment in time - or return on investment (ROI) - how much incremental money may be generated above the cost of the investment. Payback is frequently used for relatively short term projects - less than two years in length. ROI is frequently used to identify the optimal opportunity among a portfolio of opportunities.

Cost is what it costs to produce and to deliver your organization product/service to the customer. Price must be higher than the costs to generate a profit. Profit is simply the "cost of being in business in 
the future". Without a profit or surplus, an organization will simply cease to exist.

For many technology-based products and services, the cost to produce and deliver the initial product offering is above the actual costs. As the organization produces and delivers more products / services, it become significantly more efficient - especially in the early stages of the product/service life cycle - that costs drop significant. Many technology based products/services reduce the cost of production and delivery by $20 \%$ to $30 \%$ as the accumulated production doubles. This phenomenon is frequently referred to as the experience curve and is associated with the Boston Consulting Group (Henderson, 1973 \& Ghemawat 1985). The experience curve partially explains by new technology products become dramatically less expensive through time.

Questions: What the price of your organization's product/service? How was it determined?

At your current price how many units will sell? How many units will you sell if your organization increases / decreases the price by $10 \%, 15 \%$, or $20 \%$ ?

What are the costs of producing and delivering your organization's product / service at different sales volumes?

\section{Promotion}

Promotion is critical for the marketing success of research and scientific organizations. A potential customer cannot purchase a product or service that they do not know about. To effectively allocate marketing resources, the research and scientific organization should research the purchasing decision processes of the organizations' targeted customers. Without knowledge of the purchasing decision process, how can the research and scientific organization provide the 
necessary information to shepherd the purchase process to a successful conclusion?

Virtually all promotion communications via advertising, public relations, the internet, personal selling, trade shows, etc. should stress the benefits and related value of the organization's product or service to the customer. University and research organizations promote their competencies and services in academic journals and by sending the researchers to academic conferences and via personal contacts. Scientifically based products or services may be communicated their benefits to satisfy a customer via both traditional and social media.

Whatever media utilized, all marketing communications follow the AIDAS communication mnemonic - attention, interest, desire, action, and satisfaction - to guide the potential customer through the purchase process.

Questions: What is your organization's promotional strategy?

Does your organization have clearly defined and quantifiable communication objectives?

Does your organization's promotional strategy support its business strategy and positioning?

How is your organization measuring the effectiveness of its promotional strategy on its customers and noncustomers?

Is a trained and skilled marketing professional leading your organization's tactical marketing efforts?

\section{Physical Distribution}

Once the customer elects to purchase your organization's services or products, how does the organization transfer the "product" from where it is produced to where it is consumed? This is called physical distribution. In services, the physical distribution chain tends to be short such as a patient's consultation with medical specialist. The service is consumed as it is produced. Scientific products tend to 
towards a longer physical chain which is frequently global in scope. The art of managing optimizing the physical distribution chain is often referred to as supply chain management. Some organizations offer both services and products simultaneously such as Amazon which offers facilitation of technology (such as their cloud computing services, AWS) and physical products (such as items purchased through their retail website).

Significant issues for research and scientific organizations are:

1. The service or product due to its technical and complex nature may require significant training and educational resources during the startup phase and

2. The product may require frequent post sales service to optimize the customer's usage.

Questions: How will your organization deliver its service or product to the customer?

Does your organization actively manage its distribution channels?

What does your organization do to ensure customer satisfaction doing the initial acquisition phase?

How does your organization handle post purchase service and related issues?

\section{Personnel}

Nothing happens until there is a sale. The most critical decision for marketing of research and scientific organizations are the individuals assigned to marketing and sales. There are two common pitfalls in selecting these individuals. The first is that organizations often fail to appreciate the intrinsic importance of the marketing and sales role; they do not budget for it, they do not resource it, as a result they sit on innovative technology, and fail to close sales. The second major pitfall 
is that the organization does appreciate the role of marketing, but it assigns their most knowledgeable technical person to the marketing task rather than their most effective communicator. The organization's logic is often that the most knowledgeable technical person can answer the potential customer's questions.

The marketing reality is that most potential customers do not care deeply about a "deep dive" into the service's or product's technicalities. They want some understanding of how it works but ultimately care more about the question about "what is in this for me (WIFM)?" - the product's benefits.

Questions : Who is responsible for the strategic and tactical marketing of your product?

What is their skill set?

How will their success be defined and in what time period?

How will your product be sold and by whom?

How will you compensate and reward your marketing and sales personnel to achieve optimum performance?

\section{Summary and Discussion}

The brief case study of NASA Apollo program underscores strongly that successful marketing for research and technology organizations begins with extreme clarity of what the organizations' mission are and who are its customers. The clarity of the mission acts as both the organization's "North Star" and "raison d'etre" providing both focus and direction.

Research and technology organizations are the wealth creators for societies, firms, and individuals in the 21st Century. The successful 21st Century technology organization must understand its societal role and the virtuous cycle of wealth creation so it aggressively pushes the research and scientific barriers while addressing customer needs. 
Additionally, the senior leaders of research and technology organizations must be cognizant and manage the external cultural conflicts between potential customers and the technology organization as well as the internal cultural conflicts between the scientific and technology managers and the business and economic managers whose perspectives tend toward intrinsic differences.

All organizations have marketing and sales functions which may be implicit or explicit. Successful research and technology organization have an explicit marketing and sales functions staffed by marketing and sales professionals highly educated and experienced in their fields. A common mistake made by technology organizations is to elevate the best technologists into marketing/sales roles. This generally results in unfocused marketing/sales function and the loss of the organization's best technologists.

Marketing is necessary for a technology organization's survival. Strategic marketing may be segmented into identification of market need, customer segmentation, customer targeting, and product positioning. Tactical marketing (also known as Sales) may be segmented product, price, promotion, physical distribution, and most importantly personnel. It must emphasized that each of the sales elements must be perceived by the target customers as a tightly integrated whole. If one element is "out of line" such as asking a high price relative to the product value, no economic transaction will take place. If the organization fails to allocate enough promotional resources, then no economic transaction will take place since potential customers cannot buy what they do not know is available to address their needs.

This article barely scratches the surface of what a scientist or technology needs to know about marketing but will give them some context by outlining a conceptual framework for successful marketing and sales for science-based organizations. However, it barely touches the challenges of implementing actions based on understanding the marketing and sales processes. 


\section{Bibliography}

1. American Marketing Association (2018). https://www.ama.org/AboutAMA/Pages/ Definition-of-Marketing.aspx

2. Data Market (December 5, 2018). DataMarket: https://datamarket.com/ data/set/1xdu/gdp-per-capita-constant-us-millions\#!ds =1xdu!208h=1g\&display=line

3. Drucker, P. (2008). The Five Most Important Questions You Will Ever Ask about Your Organization. San Francisco, California: Jossey-Bass

4. Drucker, P. (1973 \& 1985). Management: Revised Edition. New York: HarperCollins.

5. Dubinskas, F. (1988). Janus Organizations: Scientists \& Managers. Making Time: Ethno graphics of High Technology Organizations.

6. Folger, J. (August 29, 2012). The ROI of Space Exploration. Investopedia, https://www.investopedia.com/financial-edge/0812/the-roi-of-space-exploration.aspx

7. Fowler, W. (July 21, 2014). Anniversary Shows US that NASA and Space Exploration are Worth Their Costs. UT News, https:/news.utexas.edu/2014/07/21/anniversaryshows-us-that-nasa-and-space-exploration-are-worth-their-costs

8. Ghemawat, P. (March 1985). Building Strategy on the Experience Curve. Harvard Business Review, https://hbr.org/1985/03/building-strategy-on-the-experience-curve

9. Henderson, B. (1973). The Experience Curve Reviewed. Perspectives. Boston: Boston Consulting Group, https://www.bcg.com/documents/file13904.pdf

10. Kroll, L.\& Dolan, K. (March 6, 2018). Meet the Members of the Three-Comma Club The 2018 List. Forbes Magazine.

11. Levitt, T. (July August 1960). Marketing Myopia. Harvard Business Review, 38, 45-56.

12. Lovelock, C. \& Wirtz, J. (2011). Services Marketing: People, Technology, Strategy, 7th ed. Upper Saddle River, New Jersey, Prentice Hall.

13. Romer, P. (October 1990). Endogenous Technological Change. Journal of Political Economy 98, no. 5, S71-S102.

14. Solow, R. (August 1957). Technical Change and the Aggregate Production Function. The Review of Economics and Statistics, MIT Press, Vol. 39, No. 3, pp. 312-320.

15. Stevens, G. \& Burley, J. (1997). 3,000 raw ideas = 1 commercial success! ResearchTechnology Management, 40:3, 16-27, DOI: 10.1080/08956308.1997.11671126

16. Stirone, S. (November 4, 2015). The Real Cost of NASA Missions. Popular Science, https:/www.popsci.com/real-cost-nasa-missions

17. Von Hippel, E. (July 1976). The Dominant Role of Users in the Scientific Instrument Innovation Process. Research Policy 5, no. 3, 212-239, doi:10.1016/00487333(76)90028.7.

18. Wang, J. (October 8, 2018). Scholar becomes 91st person associated with UChicago to receive Nobel Prize. UChicago News: https://news.uchicago.edu/story/economist-paulromer-sb77-phd83-wins-share-nobel-prize

19. Wartzman, R. \& Crosby, L. (December 3, 2018). Under the Hood of the Management Top 250. Wall Street Journal, p. R2 \& R4-R6.

20. Zehner, W., Williams, C. \& Pletcher, G. (August, 2016). Technology Creates 21st Century Wealth - Processes, Problems, and Prognosis. Marketing of Scientific and Research Organizations Journal, vol. 20, 2, 17-38, https://doi.org/10.14611/ minib.20.03.2016.08 
21. Zehner, B. \& Pletcher, G. (October 2017). Successful Technology Commercialization Yes or No - Improving the Odds. The Quick Look Methodology and Process. Marketing of Scientific and Research Organization, vol. 25, 81-101, https: doi.org/10.14611/minib.25.09.2017.13

prof. William Bradley „Brad” Zehner II, IC2 Institute, University of Texas, Austin, Texas, United States of America - earned a PhD in executive management and leadership from the Peter F. Drucker School - Claremont Graduate University after 20+ years as a global business executive. He was formerly associate director of the IC2 Institute, a think and do tank focused on wealth creation, at the University of Texas at Austin as well as executive director of the MS in Science and Technology Commercialization Program - see https://www.mccombs.utexas.edu/MSTC at the University of Texas at Austin. Having recently retired after a 30+ year academic career, Brad Zehner is a Fellow at the IC2 Institute - The University of Texas at Austin.

Jacquelyn Anne Zehner, Facebook, Austin, Texas, United States of America - earned a BA in economics and computational neurosciences from the Claremont McKenna College. Jacquelyn Zehner studied at Tsinghua University in Beijing, China and did research at Harvard Medical School. Jacquelyn Zehner currently works for Facebook and frequently assesses job candidates and trains new Facebook employees throughout the world. 